\section{Prevention of hemoglobinopathies in Turkey}

\author{
Mehmet Akif Çürük, Erdinç Yalın, \\ Kıymet Aksoy \\ Department of Biochemistry, Faculty \\ of Medicine, Çukurova University, Adana, \\ Turkey
}

\section{Abstract}

Hemoglobinopathies are the most common genetic disorders in Turkey. The incidence of beta thalassemia and sickle cell trait (HbAS) is $2.0 \%$ and $0.3 \%$ respectively. In addition to $\mathrm{HbS}$, 51 abnormal hemoglobins and 42 different beta thalassemia mutations have been detected by DNA analysis. In Turkey, beta thalassemia and sickle cell anemia cause major health problems. For thirty years, screening programs for carriers, genetic counseling and prenatal diagnosis have sought to prevent hemoglobinopathies. In 1983, the first prenatal diagnosis center was established for sickle cell anemia and beta thalassemia at Hacettepe University, Ankara. After many populationscreening studies, a law was passed in 1993 by the Turkish Parliament for the eradication of hemoglobinopathies. Forty-one premarital screening centers were set up by the Ministry of Health in the 33 provinces where most of the transfusion-dependent thalassemic patients live. The mothers at risk for hemoglobinopathies were given genetic counseling and directed to prenatal diagnosis centers. Since 1990, four prenatal diagnosis centers have been established at university hospitals in Adana, Antalya, stanbul and zmir. A total of 5255 prenatal diagnoses have been made for sickle cell anemia and beta thalassemia in 5 centers; 1338 fetuses have been diagnosed as homozygous or compound heterozygotes for hemoglobinopathies. Prenatal diagnosis was performed on families who had decided to terminate the pregnancy if it were to be found that the fetus was affected.

\section{Introduction}

Turkey is a large country located on the European and Asian continents. The country has a population of 73,722,988 and covers a total area of $783,562 \mathrm{~km}^{2}$. Due to the presence of various ancient civilizations, there is great genetic diversity. Twenty percent of the beta thalassemia mutations (42 of 200) and 5\% of abnormal hemoglobins (52 of 1000) reported worldwide have been detected in Turkey. ${ }^{1-11}$ Beta thalassemia is seen all over the country but sickle cell anemia is peculiar to the Çukurova region in southern Turkey. The incidence of beta thalassemia and sickle cell trait for the country as a whole is $2 \%$ and $0.3 \%$, respectively. ${ }^{4,7}$ Different regions report different percentages of beta thalassemia trait. The west and south of the country are at risk for beta thalassemia. These areas include Thrace, and the Aegean, the Mediterranean and the southeastern parts of Turkey. ${ }^{12-14}$ Although the overall frequency of beta thalassemia is $2 \%$, it reaches as high as $10 \%$ in the Thrace region. Sickle cell hemoglobin (HbS) is common in southern Turkey. Average HbAS is approximately $8.2 \%$ in the Çukurova region (Adana, Hatay and Mersin). The prevalence of carriers ranges from $3 \%$ to $44 \%$ in some villages and towns in Hatay. ${ }^{15-17}$

After the first sickle cell patient was diagnosed in 1946, several population-screening studies were carried out by different study groups. ${ }^{12-18}$ In 1983, the first prenatal diagnosis center was established at Hacettepe University in Ankara. Over eight years, a total of 101 prenatal diagnoses were made by in vitro globin chain analysis to prevent sickle cell anemia and beta thalassemia. ${ }^{19}$ This method was used at Hacettepe University for some couples whose beta globin gene mutation had been unknown until $2000 .{ }^{20}$ This was the main diagnostic procedure adopted and was performed by using fetal blood samples taken during the $18^{\text {th }}-20^{\text {th }}$ weeks of gestation. In the Gurgey 1991 study, the majority of the pregnant women had given birth to one or more affected offspring. Since the beginning of the 1990s, amplification of genomic DNA by polymerase chain reaction (PCR) techniques has been adopted in prenatal diagnosis. ${ }^{21,22}$ These PCR techniques are still being adopted by using DNA isolated from chorionic villus sampling (CVS) at the first trimester of pregnancy. Later, 2 prenatal diagnosis centers were established in Turkey, in 1990 in stanbul and in 1992 in Adana. While many prenatal diagnoses were performed by PCR, molecular diversity was well documented in hemoglobinopathies. ${ }^{23,24}$

It was found that affected births had not been eradicated completely, despite the studies carried out between 1983 and 1992. Due to the high burden on the state of the medical costs of thalassemic patients, in 1993 the Turkish Parliament passed a law for the prevention and eradication of human genetic disorders. Consequently, premarital screening centers were established as pilot studies by thalassemia associations and health authorities in Adana, Hatay and Mersin in the Çukurova region. ${ }^{25-27}$ Given the success of the pilot studies, a hemoglobinopathy scientific board was set up, and in 2002 the Ministry of Health published regulations to govern the centers' activities. Since 2003, premarital screening tests have been carried out in the 33
Correspondence: Mehmet Akif Çürük, Department of Biochemistry, Faculty of Medicine, Cukurova University, Adana, Turkey.

Tel/Fax: +90.322.338.7282.

E-mail: akif@cu.edu.tr

Key words: sickle cell anemia, beta thalassemia, hemoglobin variant, prenatal diagnosis.

Acknowledgments: the authors would like to thank Ministry of Health of Turkey, Department of Mother-Child Health and Family Planning, Ankara, Turkey and Prof. Dr. Ferda 0zkinay from Department of Genetics, Faculty of Medicine, Ege University, İzmir.

Received for publication: 6 September 2011. Revision received: 15 July 2012.

Accepted for publication: 26 September 2012

This work is licensed under a Creative Commons Attribution 3.0 License (by-nc 3.0).

@C Copyright M.A. Çürük et al., 2013

Licensee PAGEPress, Italy

Thalassemia Reports 2013; 3:e1

doi:10.4081/thal.2013.el

provinces with the highest incidence of carriers in Turkey. For the past ten years, prenatal diagnosis procedures have been performed in coordination with the Ministry of Health and university hospitals. ${ }^{20,28-30}$

\section{Materials and Methods}

Prenatal diagnosis is still the only option that can prevent hemoglobinopathies. After screening couples who manifest the sickle cell or beta thalassemia trait, prenatal diagnosis is performed at the first trimester of pregnancy, and affected fetuses are aborted as early as possible.

\section{Blood samples and hematologic procedures for premarital screening}

Many population-screening studies were carried out in the regions in which beta thalassemia and sickle cell anemia were reported between 1993 and 2002. The main screening tests carried out were complete blood count and analysis of hemoglobin variants. Blood samples (5 mL) with EDTA as anticoagulant were taken for hematologic and hemoglobin analysis. A complete blood count (CBC) was taken using a cell counter. Hemoglobin variants were characterized by cellulose acetate electrophoresis. ${ }^{31} \quad \mathrm{HbA}_{2}$ was quantified by micro column chromatography for detection of beta thalassemia trait. ${ }^{32}$

Over the last ten years, the fully automated high performance liquid chromatography 
(HPLC) systems have been used for both determination of hemoglobin variants and quantification of the Hb levels. ${ }^{32,33}$ These HPLC systems are used for hemoglobin analysis and have made it easier to set up premarital screening centers. Forty-one centers have been set up in the 33 provinces with the highest incidence of beta thalassemia trait over the last decade (Figure 1). ${ }^{34}$

\section{Fetal samples and molecular proce-} dures for prenatal diagnosis

The reason for setting up the first prenatal diagnosis center for sickle cell anemia and beta thalassemia at Hacettepe University, Ankara, in 1983, was mainly to help multiparous pregnant women at risk of having a baby affected with hemoglobinopathies. Fetal blood samples were taken between the $18^{\text {th }}-20^{\text {th }}$ weeks of gestation. By using fetal blood samples, in vitro hemoglobin chain analysis was performed using ${ }^{3} \mathrm{H}$-Leucine by conventional methods. ${ }^{19}$ This proved to be a safe and reliable procedure for prenatal diagnosis for sickle cell anemia and beta thalassemia. The method was also used for some couples whose mutation had been unknown until 2000. After detection of the beta globin gene mutations of the parents, PCR-based methods are used for prenatal diagnosis.

Genomic DNA is isolated from leukocytes by conventional methods. ${ }^{35}$ Fetal DNA is isolated from CVS obtained in the $10^{\text {th }}-11^{\text {th }}$ weeks of pregnancy. Beta globin gene mutations are detected by PCR-based techniques, such as amplification refractory mutation systems (ARMS) and restriction fragment length polymorphism (RFLP). ${ }^{22,36}$ Some rare or unknown beta thalassemia mutations were characterized by DNA sequencing with the dideoxy chain termination reaction procedure. ${ }^{37}$

\section{Results}

In Turkey, there are eighty-one provinces, including cities, towns and villages. Population size and the incidence of beta thalassemia fra in 33 of these provinces are shown in Table $1 .{ }^{38-45}$ Some provinces have more than one center: 2 in Ankara, 3 in Antalya, 2 in Aydın, 2 in stanbul, and 4 in Mugla. Istanbul is the most heavily populated (total population $13,255,685)$, while Ankara is the capital and the second largest city (total population $4,771,716)$ in Turkey.

Forty-one premarital screening centers have been set up in 33 provinces by the Ministry of Health over the last ten years. The couples at risk for hemoglobinopathies have been given genetic counseling and directed to prenatal diagnosis centers. The percentage of the cou-
Table 1. Population size and frequency of -thalassemia trait in the 33 provinces.

\begin{tabular}{|c|c|c|c|c|c|}
\hline & & & ulation size in & & Frequency of $\beta$ - \\
\hline & Province & Total & $\begin{array}{l}\text { Districts and } \\
\text { city centers }\end{array}$ & $\begin{array}{l}\text { Towns and } \\
\text { villages }\end{array}$ & thalassemia \\
\hline 1 & Adana & $2,085,225$ & $1,836,432$ & 248,793 & $3.7(39)$ \\
\hline 2 & Ankara & $4,771,716$ & $4,641,256$ & 130,460 & $2.0(40)$ \\
\hline 3 & Antalya & $1,978,333$ & $1,392,974$ & 585,359 & $13.1(39)$ \\
\hline 4 & Aydın & 989,862 & 588,552 & 401,310 & $5.1(39)$ \\
\hline 5 & Batman & 510,200 & 373,388 & 136,812 & - \\
\hline 6 & Bilecik & 225,381 & 173,389 & 51,992 & - \\
\hline 7 & Burdur & 258,868 & 159,508 & 99,360 & - \\
\hline 8 & Bursa & $2,606,495$ & $2,308,574$ & 296,921 & $1.7(39)$ \\
\hline 9 & Çanakkale & 490,397 & 269,035 & 221,362 & - \\
\hline 10 & Denizli & 931,823 & 641,093 & 290,730 & $2.6(39)$ \\
\hline 11 & Diyarbakır & $1,528,958$ & $1,090,172$ & 438,786 & $3.6(39)$ \\
\hline 12 & Düzce & 338,188 & 194,128 & 144,060 & - \\
\hline 13 & Edirne & 390,428 & 261,920 & 128,508 & $6.4(39)$ \\
\hline 14 & Erzurum & 769,085 & 489,486 & 279,599 & $0.6(41)$ \\
\hline 15 & Eski ehir & 764,584 & 681,854 & 82,730 & - \\
\hline 16 & Gaziantep & $1,700,763$ & $1,501,566$ & 199,197 & $1.84(42)$ \\
\hline 17 & Hatay & $1,480,571$ & 743,439 & 737,132 & $4.6(39)$ \\
\hline 18 & Isparta & 448,298 & 311,064 & 137,234 & $2.4(39)$ \\
\hline 19 & Istanbul & $13,255,685$ & $13,120,596$ & 135,089 & $4.5(39)$ \\
\hline 20 & İzmir & $3,948,848$ & $3,606,326$ & 342,522 & $4.8(39)$ \\
\hline 21 & Kahramanmara & $1,044,816$ & 636,828 & 407,988 & $2.8(43)$ \\
\hline 22 & Karaman & 232,633 & 159,834 & 72,799 & - \\
\hline 23 & Kayseri & $1,234,651$ & $1,064,164$ & 170,487 & - \\
\hline 24 & Kırklareli & 332,791 & 219,333 & 113,458 & $3.4(39)$ \\
\hline 25 & Kocaeli & $1,560,138$ & $1,459,772$ & 100,366 & $0.8(44)$ \\
\hline 26 & Konya & $2,013,845$ & $1,486,653$ & 527,192 & $2.0(45)$ \\
\hline 27 & Kütahya & 590,496 & 383,572 & 206,924 & - \\
\hline 28 & Manisa & $1,379,484$ & 924,267 & 455,217 & \\
\hline 29 & Mersin & $1,647,899$ & $1,281,048$ & 366,851 & $2.3(39)$ \\
\hline 30 & Muğla & 817,503 & 350,050 & 467,453 & $4.5(39)$ \\
\hline 31 & Sakarya & 872,872 & 646,899 & 225,973 & - \\
\hline 32 & Şanlıurfa & $1,663,371$ & 922,539 & 740,832 & $6.4(39)$ \\
\hline 33 & Tekirda & 798,109 & 545,481 & 252,628 & - \\
\hline Total & (33 provinces) & $53,662,316$ & $44,465,192$ & $8,905,394$ & - \\
\hline Turkey & (81 provinces) & $73,722,988$ & $56,222,356$ & $17,500,632$ & - \\
\hline
\end{tabular}

Table 2. Results of prenatal diagnosis centers in Turkey.

\begin{tabular}{lccc} 
Province & No. fetuses & No. affected fetuses & Center \\
Adana & 3616 & 903 & Çukurova University \\
Ankara & 947 & 261 & Hacettepe University \\
\hline Antalya & 407 & 105 & Akdeniz University \\
İstanbul & 70 & 14 & Bogaziçi University \\
İzmir & 215 & 55 & Ege University \\
Total & 5255 & 1338 & 5 \\
\hline
\end{tabular}


ples screened at the centers has reached 81 per cent at six years. ${ }^{46}$

A total of 5255 prenatal diagnoses have been made for sickle cell anemia and beta thalassemia in five centers at university hospitals since 1983. A summary of the results is presented in Table $2 .{ }^{20,23,29,30}$

A total of 1338 affected fetuses were homozygous or compound heterozgotes for hemoglobinopathies..$^{20,23,29,30}$ Two hundred and seventeen fetuses were diagnosed by in vitro globin chain analysis at Hacettepe University Hospital in Ankara. ${ }^{20}$ The rest of the results (3.739) were detected by DNA analysis in 5 prenatal diagnosis centers.

Frequency and type of beta thalassemia mutations in couples at risk are shown in Table $3 .^{20,23,29,30}$ The IVS1-110 G>A mutation was the most common. The ten most common mutations account for $77.1-95.2 \%$ of all the beta thalassemia mutations.

In Turkey, genetic heterogeneity of hemoglobinopathies was well documented during the prenatal diagnosis and population screening. In addition to $\mathrm{HbS}, 51$ hemoglobin variants and 42 different beta thalassemia mutations were found in the country as a whole. The lists of beta thalassemia mutations and hemoglobin variants are shown in Tables 4 and 5, respectively. ${ }^{6-11,20,30,40,47-50}$

\section{Discussion}

Hemoglobinopathies are the most common genetic diseases causing health problems in the world. Sickle cell anemia and beta thalassemia constitute the majority of the hemoglobin disorders in Turkey. Unfortunately, there is no ultimate cure for these diseases, and prevention is the best option for families at risk. Since 1983, prenatal diagnosis has been a well-accepted solution in Turkey for prevention of the hemoglobinopathies.

Hemoglobinopathies are quite heterogeneous in the Turkish population. Up to now, more than 42 different point mutations in the beta globin gene and 52 hemoglobin variants have been characterized in the country. The seven most common beta thalassemia mutations alone account for approximately $72 \%$ of the total number of mutations found in the Çukurova region. In addition to $\mathrm{HbS}$, there are some rare $\mathrm{Hb}$ variants, such as $\mathrm{HbC}, \mathrm{HbD}$ and $\mathrm{HbE}$, and also, more rarely, Hb Sarrebourg. ${ }^{50}$ Due to molecular diversity, in some couples at risk for hemoglobinopathies prenatal diagnosis requires time. For this reason, it is strongly recommended that mutation analysis should be detected before pregnancy.

All premarital screening centers were certified over nine years by the Turkish Ministry of Health. Up to now, eleven of the centers (Adana, Mersin, Hatay, Izmir, Denizli, Gaziantep, Konya, Mugla, Kocaeli, Kahramanmara, Erzurum) have published their experiences and results. ${ }^{25-27,41-45,51-54}$ Although Erzurum is included in the 33 provinces, here the incidence of beta thalassemia trait was only 0.68 per cent. ${ }^{41}$

Couples at risk for hemoglobinopathies have been directed by the centers to university hospitals for prenatal diagnosis. A large number of fetuses are diagnosed each year. It became apparent that some of the couples did not fully understand the importance of screening and genetic counseling, and so did not go to university hospitals for prenatal diagnosis. Approximately 100 affected babies are born annually because the couples had married before 2000. Consanguineous marriage also contributes significantly to affected births all over Turkey. Overall, consanguinity is approxi-

Table 3. Frequency of $\beta$-thalassemia mutations detected at the University Hospitals.

\begin{tabular}{|c|c|c|c|c|}
\hline & $\begin{array}{c}\text { Akdeniz } \\
\text { University } \\
\text { no. } 411\end{array}$ & $\begin{array}{c}\text { Bogarici } \\
\text { University } \\
\text { no. } 140\end{array}$ & $\begin{array}{c}\text { Cukurova } \\
\text { University } \\
\text { no. } 714\end{array}$ & $\begin{array}{c}\text { Hacettepe } \\
\text { University } \\
\text { no. } 1114\end{array}$ \\
\hline IVS1-110 G>A & 42.3 & 37.1 & 50.6 & 49.0 \\
\hline IVS1-1 G>A & 5.1 & 7.1 & 8.1 & 7.9 \\
\hline $\operatorname{Cod} 39 \mathrm{C}>\mathrm{T}$ & 4.9 & 6.4 & 7.1 & 3.6 \\
\hline Fsc 5 -CT & 3.4 & 2.8 & 6.0 & 2.5 \\
\hline Fsc $8-A A$ & 3.2 & 5.7 & 5.5 & 7.6 \\
\hline IVS2-1 G>A & 8.8 & 5.7 & 4.2 & 5.9 \\
\hline IVS1-6 T>C & 7.0 & 7.1 & 4.2 & 4.6 \\
\hline$-30 \mathrm{~T}>\mathrm{A}$ & 3.4 & 0.7 & 4.2 & 1.4 \\
\hline IVS2-745 C>G & 6.8 & 3.5 & 3.5 & 7.0 \\
\hline Fsc $44-C$ & 3.2 & 1.4 & 1.8 & 3.2 \\
\hline Total & 88.1 & 77.1 & 95.2 & 92.7 \\
\hline
\end{tabular}

IVS, intervening sequence; Cod, codon; Fsc, frameshift codon.

Table 4. Human $\beta$-globin gene mutations in Turkey.

\begin{tabular}{|c|c|c|}
\hline & Position & Mutation \\
\hline 1 & -101 & $\mathrm{C} \rightarrow \mathrm{T}$ \\
\hline 2 & -88 & $\mathrm{C} \rightarrow \mathrm{T}$ \\
\hline 3 & -87 & $\mathrm{C} \rightarrow \mathrm{G}$ \\
\hline 4 & -30 & $\mathrm{~T} \rightarrow \mathrm{A}$ \\
\hline 5 & -28 & $\mathrm{~A} \rightarrow \mathrm{C}$ \\
\hline 6 & 5'-UTR & $+22 \mathrm{G} \rightarrow \mathrm{A}$ \\
\hline 7 & FSC-5 & $-\mathrm{CT}$ \\
\hline 8 & FSC-6 & $-A$ \\
\hline 9 & FSC-8 & $-\mathrm{AA}$ \\
\hline 10 & FSC-8/9 & $+\mathrm{G}$ \\
\hline 11 & Cd 15 & $\mathrm{G} \rightarrow \mathrm{A}$ \\
\hline 12 & FSC 22-24 & -AAGTTGG \\
\hline 13 & Cd 30 & $\mathrm{G} \rightarrow \mathrm{C}$ \\
\hline 14 & IVS-I-1 & $\mathrm{G} \rightarrow \mathrm{A}$ \\
\hline 15 & IVS-I-1 & $\mathrm{G} \rightarrow \mathrm{C}$ \\
\hline 16 & IVS-I-1 & $\mathrm{G} \rightarrow \mathrm{T}$ \\
\hline 17 & IVS-I-2 & $\mathrm{T} \rightarrow \mathrm{A}$ \\
\hline 18 & IVS-I-5 & $\mathrm{G} \rightarrow \mathrm{A}$ \\
\hline 19 & IVS-I-5 & $\mathrm{G} \rightarrow \mathrm{C}$ \\
\hline 20 & IVS-I-5 & $\mathrm{G} \rightarrow \mathrm{T}$ \\
\hline 21 & IVS-I-6 & $\mathrm{T} \rightarrow \mathrm{C}$ \\
\hline 22 & IVS-I-110 & $\mathrm{G} \rightarrow \mathrm{A}$ \\
\hline 23 & IVS-I-116 & $\mathrm{T} \rightarrow \mathrm{G}$ \\
\hline 24 & IVS-I-130 & $\mathrm{G} \rightarrow \mathrm{A}$ \\
\hline 25 & IVS-I-130 & $\mathrm{G} \rightarrow \mathrm{C}$ \\
\hline 26 & FSC-36/37 & $-\mathrm{T}$ \\
\hline 27 & Cd 37 & $\mathrm{G} \rightarrow \mathrm{A}$ \\
\hline 28 & FSC $37-39$ & $-7 \mathrm{bp}$ \\
\hline 29 & Cd 39 & $\mathrm{C} \rightarrow \mathrm{T}$ \\
\hline 30 & FSC-44 & $-\mathrm{C}$ \\
\hline 31 & FSC-74/75 & $-\mathrm{C}$ \\
\hline 32 & FSC-82/83 & $-\mathrm{G}$ \\
\hline 33 & IVS-II-1 & $\mathrm{G} \rightarrow \mathrm{A}$ \\
\hline 34 & IVS-II-654 & $\mathrm{C} \rightarrow \mathrm{T}$ \\
\hline 35 & IVS-II-745 & $\mathrm{C} \rightarrow \mathrm{G}$ \\
\hline 36 & IVS-II-848 & $\mathrm{C} \rightarrow \mathrm{A}$ \\
\hline 37 & IVS-II-849 & $A \rightarrow G$ \\
\hline 38 & 3'-UTR & $-13 \mathrm{bp}$ \\
\hline 39 & Poly A & AATAAA $\rightarrow$ AATGAA \\
\hline 40 & Poly A & AATAAA $\rightarrow$ AATAAG \\
\hline 41 & Poly A & AATAAA $\rightarrow$ AACAAA \\
\hline 42 & $290 \mathrm{bp}$ & Deletion \\
\hline
\end{tabular}

IVS, intervening sequence; Cod, codon; Fsc, frameshift codon.

In conclusion, in Turkey, a national hemoglobinopathy screening program has played a major role in lowering the rate of affected births. Last year, the Turkish Ministry of Health adopted a policy of Family Medicine 
Table 5. Human hemoglobin variants in Turkey.

\begin{tabular}{|c|c|c|}
\hline & Hemoglobin & Mutation \\
\hline 1 & O-Podova & $\alpha 30 \mathrm{Glu} \rightarrow$ Lys \\
\hline 2 & Hasharon & $\alpha 47 \mathrm{Aspu} \rightarrow \mathrm{His}$ \\
\hline 3 & Monthgomery & $\alpha 48 \mathrm{Leu} \rightarrow \operatorname{Arg}$ \\
\hline 4 & Adana & $\alpha 59$ Gly $\rightarrow$ Asp \\
\hline 5 & J-Anatolia & 61 Lys $\rightarrow$ Thr \\
\hline 6 & Ube-2 & $\alpha 68$ Asn $\rightarrow$ Asp \\
\hline 7 & Q-Iran & $\alpha 75$ Asp $\rightarrow$ His \\
\hline 8 & Moabit & $\alpha 86$ Leu $\rightarrow$ Arg \\
\hline 9 & M-Iwate & $\alpha 87 \mathrm{His} \rightarrow \mathrm{Tyr}$ \\
\hline 10 & Çapa & $\alpha 94$ Asp $\rightarrow$ Gly \\
\hline 11 & Setif & $\alpha 94$ Asp $\rightarrow$ Tyr \\
\hline 12 & G-Georgia & 95 Pro Leu \\
\hline 13 & Bronovo & 103 His $\rightarrow$ Leu \\
\hline 14 & Strumica & $\alpha 112$ His $\rightarrow$ Arg \\
\hline 15 & J-Meerut & a120 Ala Glu \\
\hline 16 & Tyne & $\beta 5$ Pro Ser \\
\hline 17 & $\mathrm{~S}$ & $\beta 6 \mathrm{Glu} \rightarrow \mathrm{Val}$ \\
\hline 18 & $\mathrm{C}$ & $\beta 6$ Glu Lys \\
\hline 19 & Ankara & $\beta 10$ Ala $\rightarrow$ Asp \\
\hline 20 & D-Ouled Rabah & $\beta 19$ Asn $\rightarrow$ Lys \\
\hline 21 & E-Saskatoon & $\beta 22 \mathrm{Glu} \rightarrow$ Lys \\
\hline 22 & G-Cousatta & $\beta 22$ Glu Ala \\
\hline 23 & D-Iran & $\beta 22 \mathrm{Glu} \rightarrow \mathrm{Gln}$ \\
\hline 24 & E & $\beta 26 \mathrm{Glu} \rightarrow$ Lys \\
\hline 25 & Knosos & $\beta 27 \mathrm{Ala} \rightarrow$ Ser \\
\hline 26 & Volga & $\beta 27 \mathrm{Ala} \rightarrow$ Asp \\
\hline 27 & Siirt & $\beta 27$ Ala $\rightarrow$ Gly \\
\hline 28 & Hakkari & $\beta 31$ Leu $\rightarrow$ Arg \\
\hline 29 & G-Copenhagen & $\beta 47 \mathrm{Asp} \rightarrow$ Asn \\
\hline 30 & Summer Hill & $\beta 52 \mathrm{Asp} \rightarrow$ His \\
\hline 31 & Hamadan & $\beta 56 \mathrm{Gly} \rightarrow \operatorname{Arg}$ \\
\hline 32 & J-Antakya & $\beta 65$ Lys $\rightarrow$ Met \\
\hline 33 & City of Hope & $\beta 69 \mathrm{Gly} \rightarrow$ Ser \\
\hline 34 & J-Iran & $\beta 77$ His $\rightarrow$ Asp \\
\hline 35 & Yaizu & $\beta 79$ Asp $\rightarrow$ Asn \\
\hline 36 & G-Szuhu & $\beta 80$ Asn $\rightarrow$ Lys \\
\hline 37 & Pyrgos & $\beta 83 \mathrm{Gly} \rightarrow$ Asp \\
\hline 38 & Istanbul & $\beta 92 \mathrm{His} \rightarrow \mathrm{Gln}$ \\
\hline 39 & N-Baltimore & $\beta 95$ Lys $\rightarrow \mathrm{Glu}$ \\
\hline 40 & Köln & $\beta 98 \mathrm{Val} \rightarrow \mathrm{Met}$ \\
\hline 41 & D-Punjab & $\beta 121 \mathrm{Glu} \rightarrow \mathrm{Gln}$ \\
\hline 42 & O-Arab & $\beta 121 \mathrm{Glu} \rightarrow$ Lys \\
\hline 43 & Beograd & $\beta 121 \mathrm{Glu} \rightarrow \mathrm{Val}$ \\
\hline 44 & Tunis & $\beta 124$ Pro $\rightarrow$ Ser \\
\hline 45 & Sarrebourg & $\beta 131 \mathrm{Gln} \rightarrow \operatorname{Arg}$ \\
\hline 46 & Brocton & $\beta 138 \mathrm{Ala} \rightarrow$ Pro \\
\hline 47 & A2Yialousa & D82 Ala $\rightarrow$ Ser \\
\hline 48 & Baskent & $128 \mathrm{Ala} \rightarrow \mathrm{Thr}$ \\
\hline 49 & Lepore-Boston & Hybrid \\
\hline 50 & P-Nilotic & Hybrid \\
\hline 51 & Costant Spring & Elonged chain \\
\hline 52 & Antalya & Deletion and insertion \\
\hline
\end{tabular}

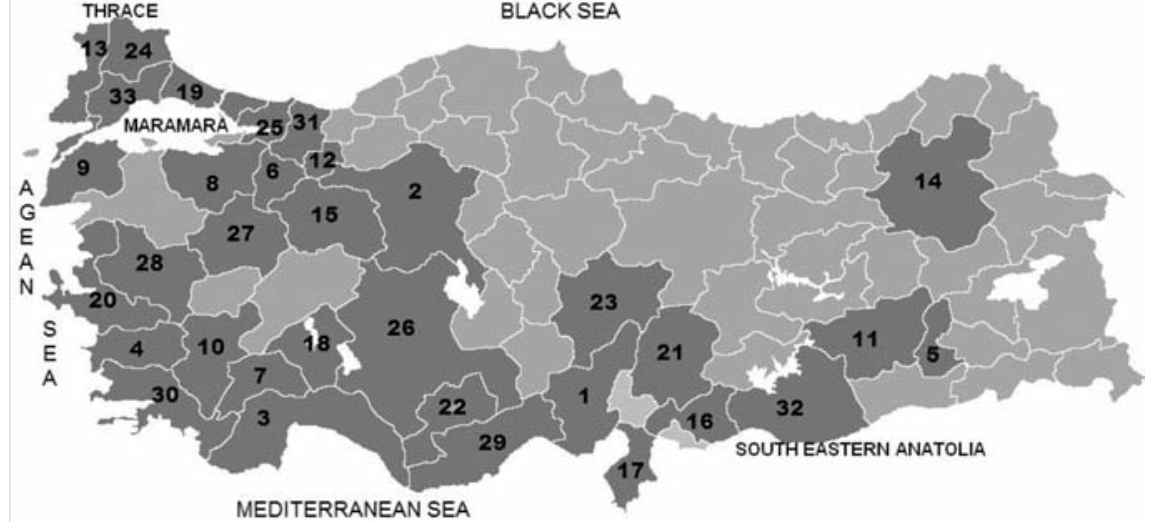

Figure 1. Provinces of premarital screening centers in Turkey.

throughout the country. Family Medicine is the medical speciality that provides continuing, comprehensive health care for individuals and their families. The scope of Family Medicine encompasses all ages, both sexes and every disease entity. If physicians examine and obtain blood samples for CBC and HPLC analysis from all pregnant women, it will be possible to eradicate hemoglobin disorders in Turkey.

\section{References}

1. Akar N, Cavdar A0, Dessi E, et al. Beta thalassemia mutations in Turkish population. J Med Genet 1987;24:378-9.

2. Aulehla-Scholz C, Basaran S, Agaoglu L, et al. Molecular basis of beta-thalassemia in Turkey: detection of rare mutations by direct sequencing. Hum Genet 1990;84: 195-7.

3. Oner R, Altay C, Gurgey A, et al. Beta thalassemia in Turkey. Hemoglobin 1990; 14:1-13.

4. Basak AN, Ozcelik H, Ozer A, et al. The molecular basis of $\beta$-thalassemia in Turkey. Hum Genet 1992;89:315-8.

5. Atalay EO, Cirakoglu B, Dincol G, et al. Regional distributions of beta-thalassemia mutations in Turkey. Int $\mathrm{J}$ Hematol 1993;57:207-11.

6. Curuk MA, Arpaci A, Attila G, et al. Genetic heterogeneity of $\beta$-thalassemia at Çukurova in Southern Turkey. Hemoglobin 2001;25:241-5.

7. Altay C. The frequency and distribution pattern of $\beta$-thalassemia mutations in Turkey. Turkish J Hematol 2002;19:309-15.

8. Huisman THJ, Carver MFH, Baysal E. A syllabus of thalassemia mutations. Augusta GA: The Sickle Cell Anemia Foundation; 1997.

9. Altay C. Abnormal hemoglobins in Turkey.
Turkish J Hematol 2002;19:63-74.

10. Akar E, Akar N. A review of abnormal hemoglobins in Turkey. Turkish $\mathrm{J}$ Hematol 2007;24:143-5.

11. Huisman THJ, Carver MFH, Efremov GD. A syllabus of hemoglobin variants. Augusta GA: The Sickle Cell Anemia Foundation; 1998. Available from: http://globin.cse. psu.edu

12. Aksoy M, Ikinew W, Mourant AE, Lehmann H. Blood groups, haemoglobins, and thalassaemia in Turks in Southern Turkey and Eti-Turks. Br Med J 1958;18:2:937-9.

13. Aksoy M, Dincol G, Erdem S. Survey on haemoglobin variants, beta-thalassaemia, glucose-6-phosphate dehydrogenase deficiency and haptoglobin types in Turkish people living in Manavgat, Serik and Boztepe (Antalya). Hum Hered 1980;30:3-6.

14. Aksoy M, Kutlar A, Kutlar F, et al. Survey on haemoglobin variants, beta thalassaemia, glucose-6-phosphate dehydrogenase deficiency, and haptoglobin types in Turks from Western Thrace. J Med Genet 1985; 22:288-90.

15. Ozsoylu S, Sahinoglu M. Haemoglobinopathy survey in an Eti-Turk village. Hum Hered 1975;25:50-9.

16. Altay C, Yetgin S, Ozsoylu S, Kutsal A. Hemoglobin S and some other hemoglobinopathies in Eti-Turks. Hum Hered 1978; 28:56-61.

17. Yüregir GT, Donma 0, Dikmen N, et al. Population studies of Hemoglobin S and other variants in Cukurova, the southern part of Turkey. Acta Haematol 1987;50: 757-65.

18. Aksoy M. Sickle-cell anemia in South Turkey; a study of fifteen cases in twelve white families. Blood 1956;11:460-72.

19. Gurgey A, Mesci L, Beksac S, et al. Prenatal diagnosis in hemoglobinopathies. DogaTurkish J Med Sci 1991;15:419-25. 